\title{
3. GEOLOGICAL SETTING OF THE CELEBES AND SULU SEAS ${ }^{1}$
}

\author{
C. Rangin ${ }^{2}$ and E. Silver ${ }^{3}$
}

\section{INTRODUCTION}

The Sulu and Celebes Seas lie to the southeast of the South China Sea, within a complex geodynamic environment marked by active arc-arc or arc-continent collision zones, subduction zones, and long strike-slip fault zones. Prior to Leg 124, neither the ages nor the mode of formation of these basins were clear. The basins are located near the zone of complex junction between the Pacific, Indian Ocean, and Philippine Sea plates (Fig. 1). They may have been related to the history of one of these plates prior to collision or be the remnants of a subducted ocean that previously extended between these major plates (the Molucca Sea or neo-Tethys Ocean). Alternatively, they may have formed by back-arc spreading processes or, as in the case of the South China Sea, as a result of continental rifting unrelated to arc activity.

Numerous models have been proposed for the opening of small ocean basins in a position marginal to a continent or a piece of continent by convergent boundaries. In the west Pacific region (Fig. 1), a widely accepted model is that of extension in the back-arc area (Chase, 1978; Molnar and Atwater, 1978; Uyeda and Kanamori, 1979). This model might be applied to the Sulu Sea (Mitchell et al., 1986; Rangin, 1989) but not obviously to the Celebes Sea.

The South China Sea has been interpreted as an Atlantic type (Taylor and Hayes, 1980) or a pull-apart basin, possibly related to transcurrent shear zones controlled by intracontinental deformation processes (Tapponnier et al., 1982; Lallemand and Jolivet, 1985). The Atlantic-type model could be extended to other marginal or intracontinental basins of the Eurasian margin, such as the Japan Sea or the Yellow Sea (Taylor and Rangin, 1988). Paleogene rifting and Oligocene-Miocene spreading from Borneo to Japan and the suspected presence of dominantly north-south right slip faults along the east Asian margin suggests that an extensional stress regime was present along the Eurasian margin during this period.

These marginal basins could also be interpreted as trapped fragments from a larger ocean, as a consequence of subduction zone flipping or jumping along the volcanic arcs bordering these basins. If these basins have had an exotic origin relative to Asia, their stratigraphic histories will be unrelated to the Eurasian continental margin.

The Celebes and Sulu seas are deep (4000-5000 m) restricted basins located between the island of Borneo to the west and the north-south elongated Philippine Archipelago to the east. They are part of a succession of subparallel oceanic basins trending roughly northeast. Separating the basins from South China to Banda are narrow, elongated ridges such as the Cagayan Ridge,

\footnotetext{
${ }^{1}$ Rangin, C., Silver, E., von Breymann, M. T., et al., 1990. Proc. ODP, Init. Repts., 124: College Station, TX (Ocean Drilling Program).

2 Laboratoire de Géologie Structurale, T-26-0 E1, Université Pierre et Marie Curie, 4 Place Jussieu, 75252 Paris Cedex, France. 95064 .
}

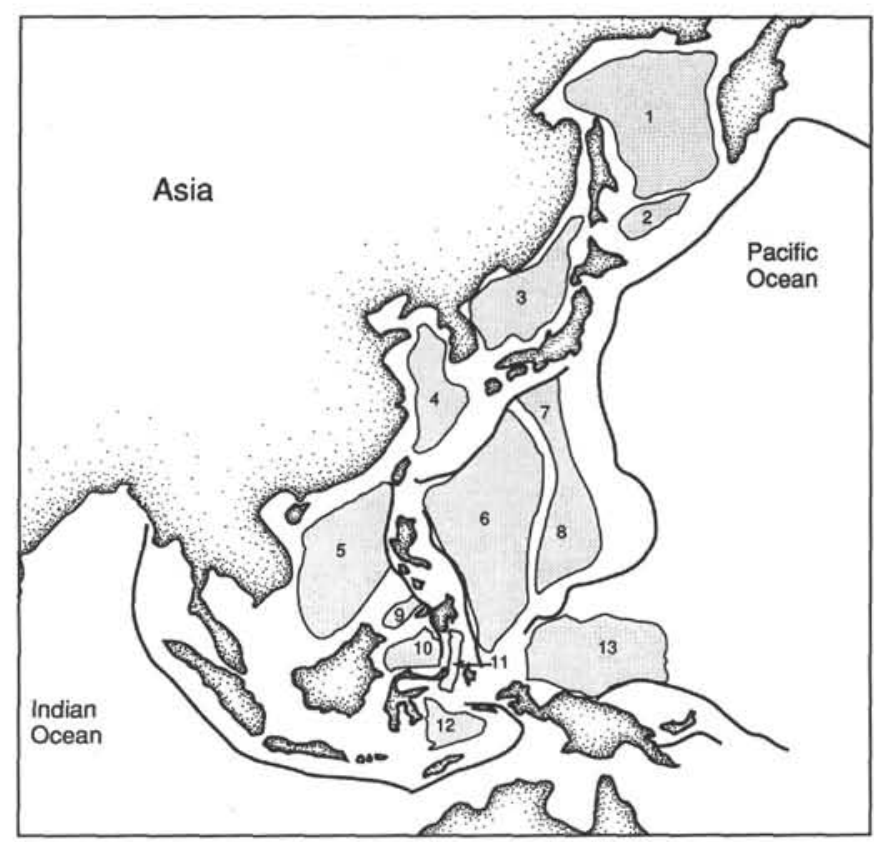

Figure 1. Setting of marginal basins in the northwest Pacific. Heavy lines are surface traces of subduction zones. Basins are (1) Okhotsk, (2) Kurile, (3) Sea of Japan, (4) East China and Yellow seas, (5) South China Sea, (6) West Philippine, (7) Shikoku, (8) Parece Vela, (9) Southeast Sulu, (10) Celebes, (11) Molucca Sea, (12) Banda Sea, and (13) Caroline.

the Palawan and Sulu archipelagos, the arms of Sulawesi, and the Sula platform (Fig. 2).

\section{CELEBES SEA}

The age of the Celebes Sea (Fig. 2) was not known with certainty prior to Leg 124. Several lines of evidence led Weissel (1980) to infer an Eocene age for the crust. The primary evidence is the magnetic anomaly pattern that he correlated with Anomalies 18-20 (42-46 Ma) from the west Philippine Basin, the south Atlantic, and the southeast Pacific. The anomalies in the Celebes Basin trend northeast and are young to the south. Additional information comes from heat-flow and depth data. The average heat flow in the basin is $66 \mathrm{~mW} / \mathrm{m}^{2}(1.58 \mathrm{hfu})$, consistent with an Eocene age, though not tightly constrained. Basement depths in the Celebes Basin (Fig. 3), corrected for sediment load, lie between 5 and $6 \mathrm{~km}(5.2 \mathrm{~km}$ at Site 767$)$. These depths imply ages of up to $65 \mathrm{Ma}$. Weissel (1980) urged some caution in determining age vs. depth in marginal basins because Sclater et al. (1976) found basement depths in the west Philippine Basin to be several hundred meters greater than that predicted from the Sclater et al. (1971) curves. Weissel noted, however, that the west Philippine Basin has thinner than normal crust, whereas the Celebes Basin has normal ocean crustal thickness. 


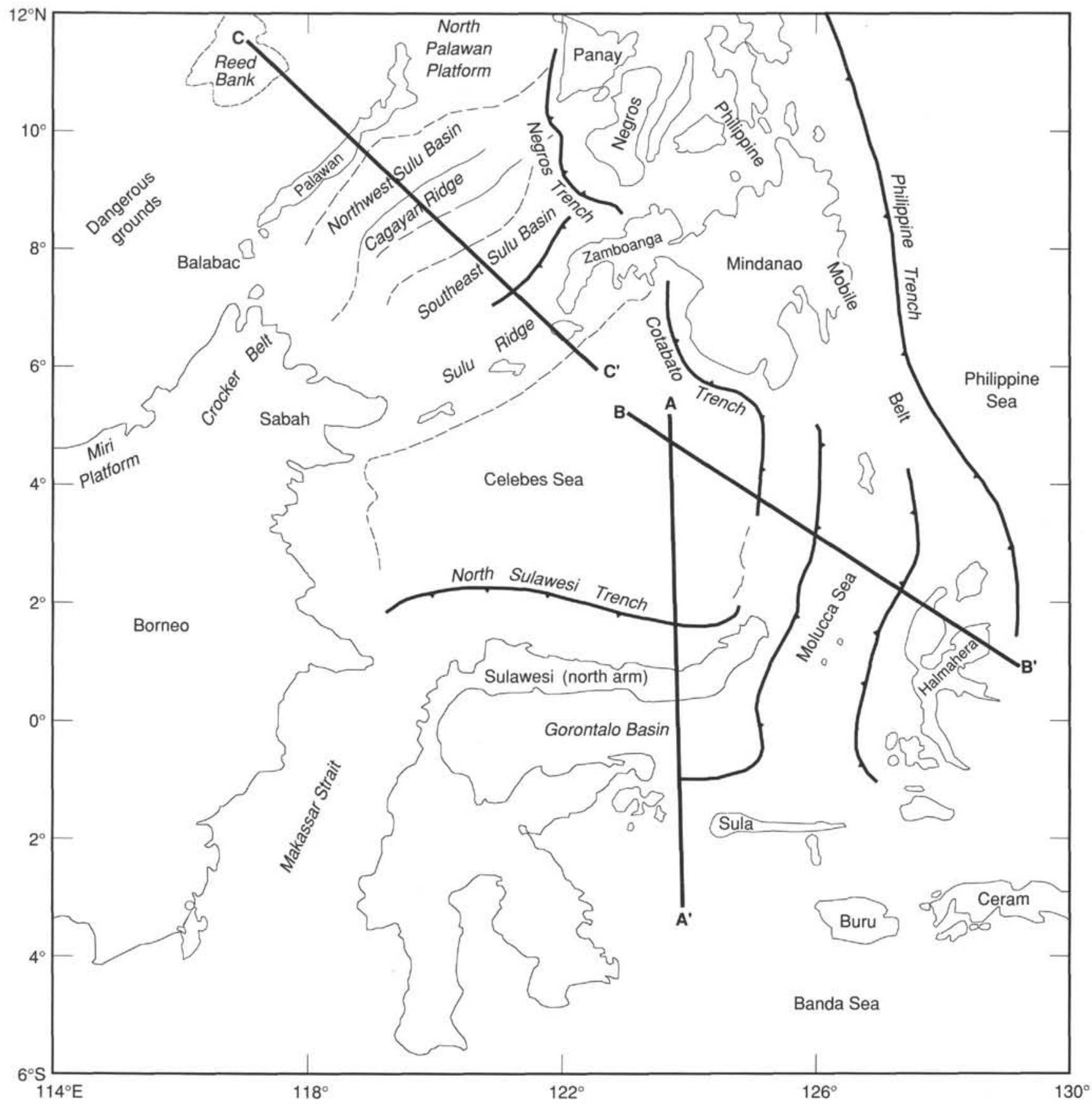

Figure 2. Structural sketch map of the Sulu-Celebes seas area, modified from Hamilton (1979), showing the location of Figures 3 and 4 as transects $\mathrm{AA}, \mathrm{BB}^{\prime}$, and $\mathrm{CC}^{\prime}$.

Weissel (1980) also attempted to determine the latitude of formation of the Celebes Sea, using the method of magnetic anomaly skewness (Shouten and Cande, 1976). He was not able to show that the Eocene paleolatitude differs from that of the present, and concluded that the Celebes Sea formed in low latitudes. This finding is consistent with paleomagnetic studies in Borneo (Haile et al., 1977) and Malaysia (Jarrard and Sasajima, 1980).

Lee and McCabe (1986) reinterpreted the magnetic anomalies in the Celebes Sea and proposed a hypothesis linking the Sulu, Celebes, and Banda seas as becoming successively older from north to south (42-47 Ma for Sulu, 65-72 Ma for Celebes, and $130 \mathrm{Ma}$ for Banda). The anomalies used for the Banda and
Sulu seas include those lying along young volcanic ridges and parts of adjacent volcanic arcs, so there is some question concerning the data base used for the Sulu and Banda seas. Their age for the Celebes Sea, however, is based on simply a different interpretation of the same magnetic anomalies used by Weissel (1980), and it agrees with that predicted from age vs. depth considerations (Sclater et al., 1976).

\section{SULU SEA}

The Sulu Basin is one of the smallest marginal basins of the western Pacific region (Figs. 1 and 2). This basin is elongated northeast-southwest between the Visayas Archipelago in the Philippines and Sabah, Borneo. It is $400 \mathrm{~km}$ wide and is sepa- 

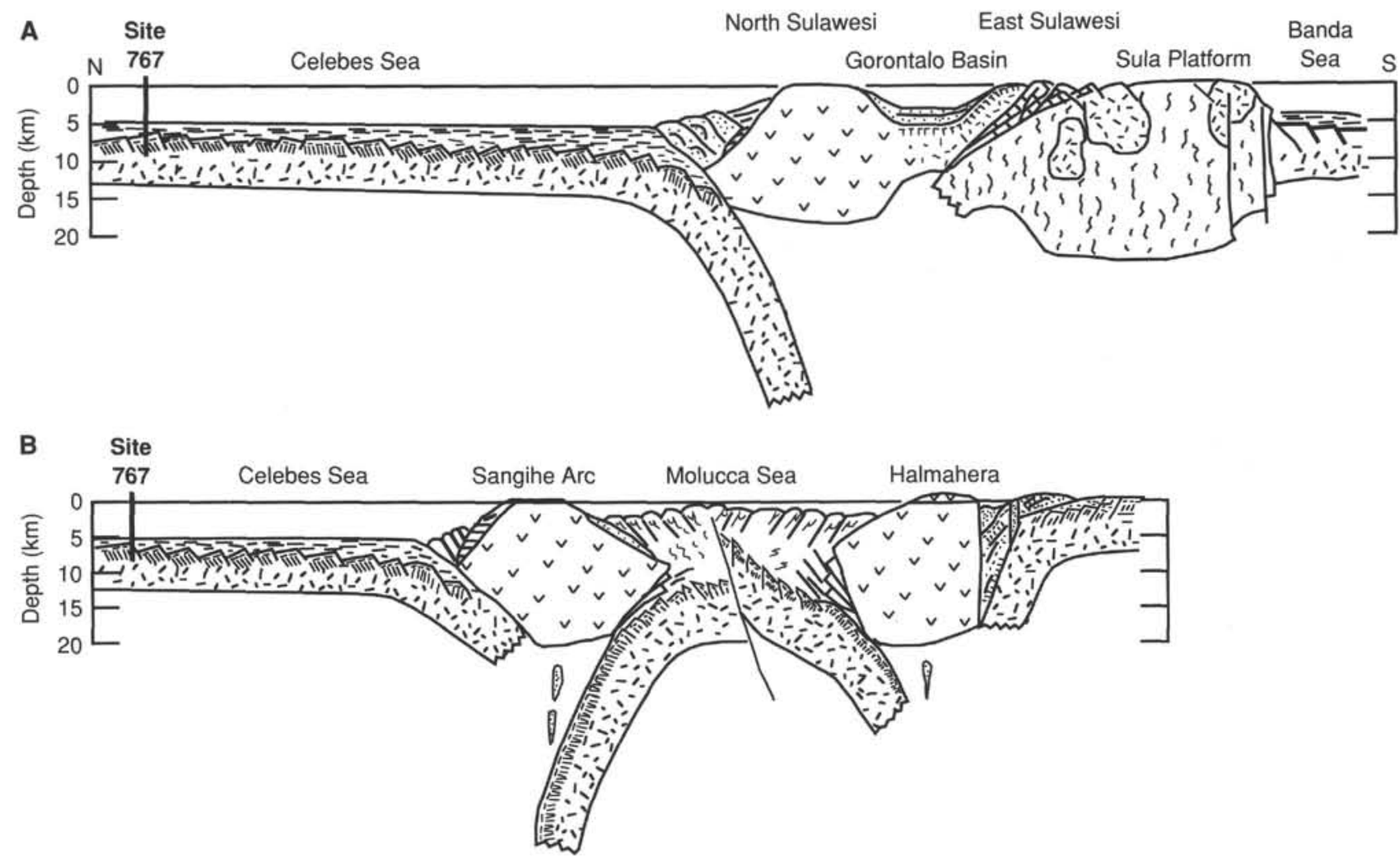

Figure 3. Interpretive cross-sections of the Celebes Sea, located on Figure 2. A. Celebes Sea to the Banda Sea (transect AA'). B. Celebes Sea to Halmahera (transect BB').

rated into two distinct sub-basins by a major bathymetric high, the Cagayan Ridge. Seismic refraction data (Murauchi et al., 1973) have revealed thick crust $(>10 \mathrm{~km})$ in the northwest basin, in contrast with the thin $(6 \mathrm{~km})$ and relatively flat acoustic basement of the southeast Sulu sub-basin (Mascle and Biscarrat, 1978).

The northwest basin is distinguished by a large, complex terrace in the northeast, with water depth ranging from 1000 to $1800 \mathrm{~m}$, and a plain of about $2000 \mathrm{~m}$ in the southwest, filled by relatively undeformed sediments, lying disconformably on the underlying deformed strata. This disconformity can be traced southwestward in the Balabac area, where it was drilled and dated as early middle Miocene (Beddoes, 1976). The southeast basin, in which the greatest depths range from 4500 to $5100 \mathrm{~m}$, shows acoustic basement overlain by a $1-2 \mathrm{~km}$ thick, seismically coherent sedimentary sequence. This deep basin is characterized by crustal thicknesses and seismic basement characteristics typical of oceanic crust (Fig. 4).

Heat-flow values reported from the Sulu Sea (Anderson et al., 1978; Kudrass et al., unpubl. data) cover an unusually wide range from $0.69 \mathrm{hfu}\left(25 \mathrm{~mW} / \mathrm{m}^{2}\right)$ to $4.39 \mathrm{hfu}\left(184 \mathrm{~mW} / \mathrm{m}^{2}\right)$. High values indicating thermal anomalies are located close to the deformation front of the Sulu Negros trench and are interpreted by Kudrass et al. (unpubl. data) as an effect of fluid flow in front of the actively advancing accretionary wedge. There is a diversity of geophysical and geological data from the Sulu Sea. Two long seismic refraction profiles and magnetic measurements were collected by the Vema in 1967 (Murauchi et al., 1973), and multichannel seismic surveys were conducted across this basin (Mascle and Biscarrat, 1978; Hinz et al., unpubl. data, and this volume).

The Sulu Sea is an oxygen-deficient basin (Linsley et al., 1985). Study of such a basin has impact on paleoenvironments associated with potential hydrocarbon sources, as well as on better understanding of the relationships between stagnant basins and the global oceanic-atmospheric climate systems. The silled Sulu Sea basin serves as a natural laboratory for studying sedimentation in an oxygen-deficient basin through a relatively long period of time and for studying the effect of sea-level changes on the expected anoxic-oxic cycles of sedimentation. Periodic lowering of the sea level during the latest Cenozoic would have been particularly well registered in this semi-isolated basin. During the Tertiary, similar temporary isolation could have resulted from local collisions of arc terranes with the drifted continental margin of China, the ages of which are wellcontrolled onshore.

Surface sedimentation in the outer Sulu Sea reflects biogenic and terrestrial input. The carbonate compensation depth (CCD) for the basin is at $4500 \mathrm{~m}$, and sedimentation rates increase above this depth. Below $4500 \mathrm{~m}$, turbidite sedimentation is important in the Sulu Trough (Exon et al., 1981).

These basins are bounded by prominent ridges that are relatively parallel to the elongation of the basin (Figs. 2 and 3 ). These ridges are either covered by reefs or are emerging, as in the Palawan and Sulu archipelago, significantly limiting water mass circulation between the Sulu Sea and the Celebes and South China seas.

\section{PALAWAN}

The Sulu and Celebes basins are rimmed by active or recently active thrust belts. The Palawan wedge fringes the Sulu Basin to the north (Fig. 2). The South Palawan, Balabac, and Banggi islands are regarded as the emergent part of the Palawan accretionary prism (Hamilton, 1979; Holloway, 1982). This wedge is inferred to have collided during early middle Miocene time with a continental terrane exposed in the North Palawan and Cala- 

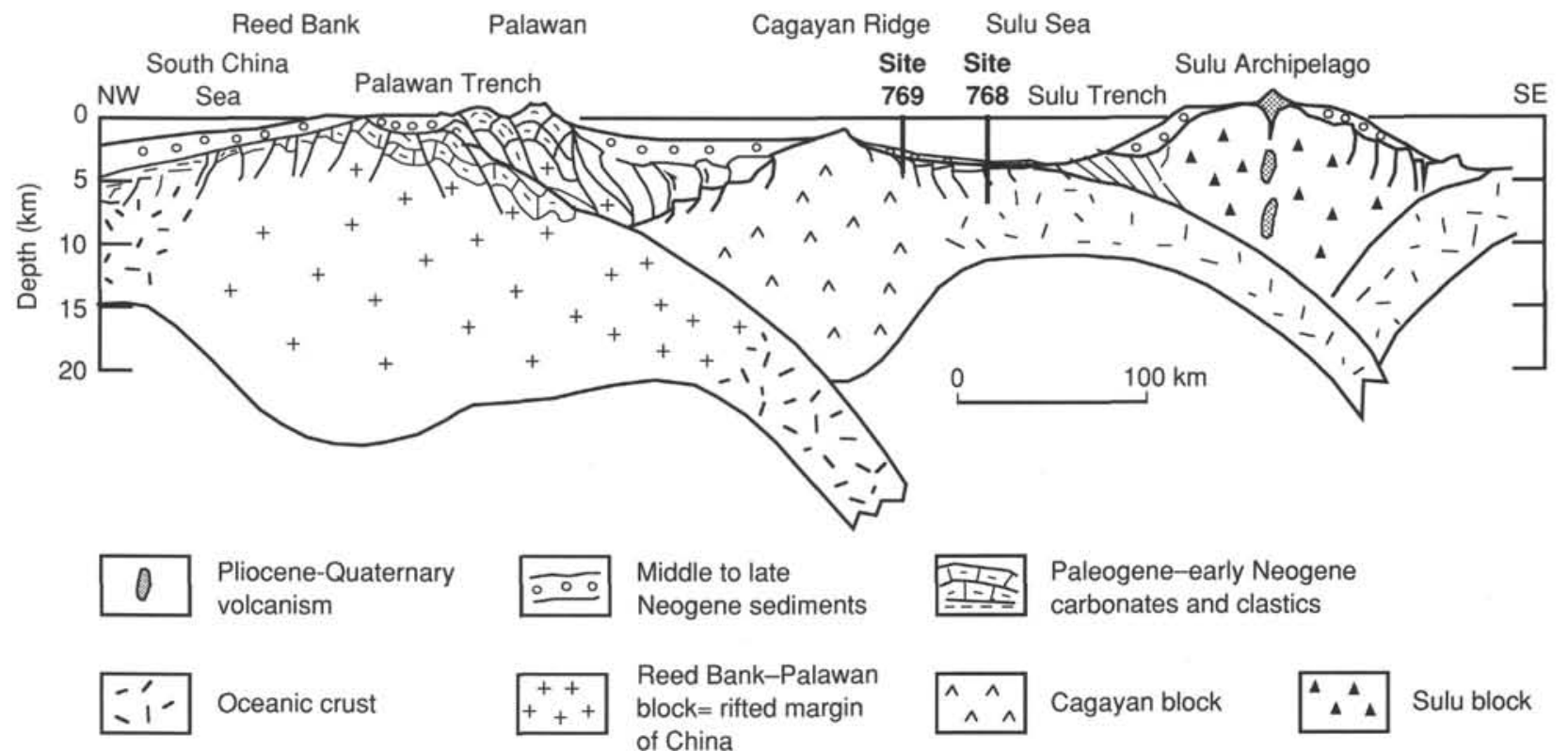

Middle to late

Neogene sediments

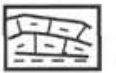

Paleogene-early Neogene carbonates and clastics

Reed Bank-Palawan block $=$ rifted margin of China

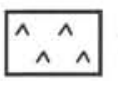

Cagayan block

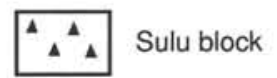

Figure 4. Interpretive cross-section of the Sulu Sea, located on Figure 2 as transect CC'.

mian islands, formed by a metamorphic basement and late $\mathrm{Pa}$ leozoic through Mesozoic clastic sediments and limestones (Fontaine et al., 1979; United Nations, 1985; Wolfart et al., 1986). Recent studies have revealed that this continental basement extends eastward into Mindoro Island (Rangin et al., 1985, 1988; Marchadier and Rangin, 1989; Faure et al., 1989). Similar metamorphic rocks were dredged offshore in Reed Bank and Dangerous Grounds (Kudrass et al., unpubl. data).

The tectonic contact between this continental terrane, belonging to the drifted South China Sea continental margin, and the Palawan accretionary prism is the starved Palawan Trench (Fig. 4), interpreted as a former subduction zone active up to the beginning of the middle Miocene (Holloway, 1982). According to Holloway, the proto South China Sea was a large Mesozoic oceanic basin, subducted southward along this convergent boundary.

The accretionary wedge of central and south Palawan is composed of a complex pile of thrust slices with evident polyphase deformation. Dismembered Early Cretaceous ophiolites are imbricated with a clastic sequence of upper Paleocene-early middle Miocene age (Mitchell et al., 1986; Raschka et al., 1985; Letouzey and Sage, 1988). Amphibolites dated $40 \mathrm{Ma}$ (Raschka et al., 1985), associated with the ophiolites, as well as highly deformed and schistose Late Cretaceous sediments, suggest a prelate Eocene tectonic event. A younger event resulting in the imbrication of these Cretaceous units with Paleogene sediments is postdated by the deposition of late Miocene-early Pliocene carbonates (Letouzey and Sage, 1988), whereas the Palawan Trench is filled by disconformable middle Miocene clastics (Holloway, 1982). Imbrication of the north Palawan and central south Palawan terranes during the Miocene collision is shown by the results of the German cruises in the South China Sea and the Sulu Sea (K. Hinz, pers. comm., 1988).

Kilometer-sized ophiolite bodies are exposed in the central and southern Palawan and Balabac islands. They consist of peridotites, gabbros, metagabbros, amphibolites, and locally pillow-lavas, radiolarites, and red mudstones dated as Early Cretaceous in age (Letouzey and Sage, 1988). This complex is imbricated with Late Cretaceous-early middle Miocene clastics and carbonates. Middle Miocene tectonism is related to collision along the Palawan trench (Letouzey and Sage, 1988), but a pre-Eocene fabric (Faure et al., 1989) implies that the major de- formation and emplacement of these ophiolites is probably Eocene in age (Raschka et al., 1985; Letouzey and Sage, 1988) or pre-Eocene (Faure et al., 1989).

\section{THE CAGAYAN RIDGE}

This prominent submarine ridge divides the Sulu Sea into two sub-basins (Fig. 2), characterized by a smooth northwestern slope and a steep southeastern slope with southeast-facing normal faults (Mascle and Biscarrat, 1978). Porphyritic andesites, tuffs, vesicular fresh basalts, and pre-Quaternary sediments were recently dredged from the eastern slope of the ridge $(\mathrm{Ku}-$ drass et al., unpubl. data). Some of the sediments are shallow water with large foraminifers, indicating early to middle Miocene age. Chemical composition of the andesites (K. Hinz, pers. comm., 1988) indicates that the ridge originated as a volcanic arc. Andesites intercalated with early middle Miocene sediments are reported from central Palawan, where they are present at the top of the accretionary wedge (Letouzey and Sage, 1988). Fragments of this island arc terrane have been found also in Panay Island (Rangin, 1989), where they are incorporated into the inner wall of the Negros Trench. The same volcanic belt was traced northward in Tablas and eastern Mindoro Island (Marchadier and Rangin, 1989).

The Cagayan volcanic ridge has been interpreted as the north-facing island arc for the Palawan Trench (Holloway, 1982) as well as the remnant volcanic arc for the Sulu Arc related to northwestward subduction of the Celebes Sea (Mitchell et al., 1986; Rangin, 1989). Each of these models considered the Sulu Sea to be a back-arc basin, tentatively dated as late Oligocene or middle Miocene in age.

\section{THE SULU RIDGE}

The Celebes and Sulu basins are separated by the shallow, partly emerged Sulu Ridge, 150 to $200 \mathrm{~km}$ wide (Figs. 2 and 3), extending from western Mindanao (Zamboanga Peninsula) to northeast Borneo (Semporna and Dent peninsulas, Sabah). Islands present along that ridge are active volcanoes (Jolo, Basilan). Tawi-Tawi Island to the west is formed by dismembered ophiolites, probably similar to the ones exposed in Sabah.

A Paleogene volcanic sequence is reported by Antonio (1972) in the Zamboanga Peninsula, where it is imbricated with ophiolites and metamorphic rocks (crystalline schists, marbles, and 
amphibolites). The Sulu volcanic ridge is fringed on the northwest by a trench shallowing progressively to the southwest and deepening eastward toward its junction with the Negros Trench. No focal mechanism has been determined for this south-dipping subduction zone and related volcanoes are in a fumarolic stage. However, deformation occurs at the foot of the inner wall (Mascle and Biscarrat, 1978; Hinz et al., unpubl. data). The Sulu and Negros trenches were considered by Mitchell et al. (1986) as having initiated as back-arc thrusts along the Sulu Arc since the middle or late Miocene. This proposed flip of subduction along the Sulu Archipelago was considered to be the result of the collision of exotic terranes with a formerly southeast-facing convergent zone.

The presence or absence of a starved trench along the southern margin of that ridge is difficult to assess because of the thick sedimentary cover and the lack of appropriate multichannel seismic (MCS) data. An unpublished profile recorded by the Sonne south of Zamboanga reveals possible southeastward tilted blocks along this margin (K. Hinz, pers. comm., 1988). However, such extensional structures could be the result of back-arc extension since late Miocene-Pliocene time, after the flip of the subduction to the northern side of the archipelago (Mitchell et al., 1986; Rangin, 1989). Consequently, with the present stage of data availability, it is difficult to know how much oceanic crust was subducted along the Sulu Trench and how much of the Celebes Sea was subducted along a still hypothetical south Sulu trench. The history of sedimentation within the basins on both sides of that ridge can help to solve these problems.

\section{EASTERN BORNEO}

The Sulu Sea is fringed to the west by the Sabah ranges (Fig. 2), formed by three major tectonostratigraphic units (Rangin et al., in press).

1. The Dangerous Grounds-Miri Platform is the foreland for this belt and is formed by Cenozoic shallow-water clastics and carbonates lying disconformably on top of a composite continental basement, known on the basis of offshore dredging (Hinz and Schluter, 1985). These deposits were deformed after the middle Miocene and are presently affected by a major intraplate thrust merging into the southwest Palawan Trench. This platform is the westward extension of the Reed Bank shelf extending north of Palawan.

2. The Crocker Belt, which was thrust north and west on the platform during middle Miocene time, is a large accretionary wedge including mainly Paleogene quartz-rich turbidites and minor early Cretaceous ophiolites and melanges. Thrust faults and duplexes are widely distributed in that belt. It is the western extension of the Palawan Ridge and deformed northwest Sulu Basin.

3. The uppermost unit of Sabah is a late Oligocene-middle Miocene island arc, thrust northward above the Crocker belt during the same middle Miocene tectonic event and disconformably covered by late Neogene successor basins. This allochthonous island arc is the western extension of the Sulu Arc, but an extension of the Cagayan volcanic ridge in this area of Borneo cannot be disregarded, considering the poor data set available on that ridge.

The post-orogenic clastic deposits of Sabah extend southward along the Celebes Sea, in northeastern most Kalimantan. The basin fill represents the overlapping deltas of several major rivers, which may have also provided a large amount of sediments to the Celebes Sea. Middle Tertiary sediments are more deformed than are upper Tertiary and Quaternary ones, and folding is still going on as in Sabah. The northern and southern boundaries of the Tarakan Basin are controlled by northwesttrending $\left(50^{\circ}\right)$ strike slip faults (Tawau in Sabah and Mangkalihat peninsula in Kalimantan). These faults also extend southward into the Makassar Basin and may be related to the opening of this trough in Paleogene time (Hamilton, 1979). It has recently been suggested that the Makassar Basin and Celebes Sea are cogenetic (Jolivet et al., 1989).

\section{THE PHILIPPINE MOBILE BELT}

Toward the east, the Sulu and Celebes seas are bounded by the Negros and Cotabato trenches (Fig. 2), separating these basins from the central and southern part of the Philippine Mobile Belt (PMB) (Gervaiso, 1971). These short subduction zones are the southern extension of the Manila Trench (Lewis and Hayes, 1984). This trench enters the North Palawan Platform offshore Mindoro (Rangin et al., 1988) and connects southward with the northern Negros Trench through complex strike-slip and wrench faults (Marchadier and Rangin, 1989). Detailed bathymetry is not available to the south of Mindoro and west of Panay, but relatively deep-water channeling is expected from the South China Sea to the Sulu Sea, based on bathymetric data. West of this active and recent plate boundary, the PMB is a mosaic of allochthonous terranes extending from Luzon to Mindanao (Karig, 1983; McCabe et al., 1985; Mitchell et al., 1986).

To the north, the Negros Trench crops out in Panay Island, where the PMB collides northwestward with the Cagayan Ridge (Rangin, 1989). Mesozoic ophiolites, melanges, and Cenozoic island-arc volcanic rocks are jammed into this collision zone. Northward, progressive collision between the Cagayan Ridge and the PMB has been documented on multichannel seismic profiles by Hinz et al. (unpubl. data). Southward, subduction of the Sulu Basin along the Negros Trench was documented by Mascle and Biscarrat (1978), and related active volcanoes are known in Negros Island (Bureau of Mines and Geosciences, 1982). In Mindanao, the junction between the Negros and Cotobato trenches is marked by left lateral strike slip faults, crosscutting the northern part of the Zamboanga Peninsula (Rangin, 1989).

East of this active convergent zone, the PMB is composed of a mosaic of terranes, bounded to the east by the Philippine Trench and the East Luzon Trough (Lewis and Hayes, 1983) and dissected by the complex left lateral Philippine fault zone (Allen, 1962). The recent ages for motion along these structures suggest the PMB (or part of it) was attached to the West Philippine Basin during the major part of the Tertiary. Paleomagnetic data from the Philippine Sea Plate reveal clockwise rotation since at least Oligocene time (Louden, 1977). Uyeda and McCabe (1983) note the close correspondence between the paleoinclinations of the PBM with the Philippine Sea Plate, which suggests that these large crustal blocks have been coupled during a large part of the Tertiary. Within a substantial part of Luzon, paleomagnetic results reveal a late Miocene-Pliocene period of clockwise rotation compatible with the Philippine Sea Plate motion (Fuller et al., 1989). Opposite rotations in the 10-20 Ma interval are interpreted by Fuller et al. (1989) as the result of the collision of the PMB with the Palawan microcontinent (i.e., the drifted continental margin of the South China Sea). Complex rotations of microblocks in the central part of the PMB (McCabe et al., 1985) can be the result of this regional oblique collision and sinistral shear between the Eurasian Plate and the Philippine Sea Plate.

The initial configuration of the West Philippine Basin is consistent with a back-arc origin behind part of the PMB as it was proposed by Uyeda and McCabe (1983). The presence in the PMB of back-arc volcanism coeval with the opening of the West Philippine Basin supports this hypothesis. These volcanic-arc sequences were dated all across the belt from Panay Island to 
Bicol Peninsula (Rangin, 1989). This Paleogene volcanic arc lies disconformably on a complex set of terranes including Cretaceous island-arc sequences and ophiolites, but no continental material is known, supporting an intraoceanic origin for the PMB. Late Cretaceous (Maestrichtian) ophiolites are reported from the southern Sierra Madre of Luzon (Angat ophiolite of Karig, 1983), where they are overthrust by a Cenomanian-Eocene arc sequence (Stephan et al., 1986). To the west these ophiolites are covered disconformably by the Oligocene-Miocene Central Valley successor basin, and the whole sequence is intruded by Oligocene-Miocene granodiorites (Wolfe, 1988). Dismembered ophiolite complexes reported from the northern $\mathrm{Si}$ erra Madre and central cordillera of Luzon, and to the south in Bicol, Cebu, Leyte, Samar, and northern Mindanao, are not dated but are the imbricated Angat ophiolite with Late Cretaceous-Paleogene volcanic-arc terranes (Bureau of Mines and Geosciences, 1982). When present, thinly bedded pelagic cherts and tuffs cover the pillow basalts.

Ophiolites are found in Panay Island (United Nations, 1983) along the emerged inner wall of the Negros Trench. Ultramafics and gabbros are interthrust with red cherts, pillow basalts, and breccias associated with massive stratiform sulfides, indicating hydrothermal activity. The cherts were dated Barremian-Aptian in age (Rangin, 1989), confirming the Jurassic-Early Cretaceous age proposed by McCabe et al. (1982). The ophiolites are partly imbricated with middle Miocene andesitic rocks or are present within the early middle Miocene melange.

The geology of Mindanao is poorly known, but was interpreted in terms of Cenozoic collision of the Sangihe and Halmahera volcanic arcs (Moore and Silver, 1982; Hawkins et al., 1986). These volcanic sequences are imbricated with Late Cretaceous (?) ophiolites and are also covered disconformably by a thick sequence of clastic rocks and carbonates dated late Paleogene to early Neogene at its base. Basins with similar basement are known to the north in the Visayas region (Ilo-Ilo Basin in Panay; United Nations, 1983) and in Luzon (Cagayan Valley).

Along the western margin of the PMB, small slices or terranes of Cenozoic ophiolites are present. These ophiolitic units could represent fragments of the oceanic basins from the $\mathrm{Ce}$ lebes, Sulu, or South China seas that were dragged along the Eurasian margin during the oblique collision with the PMB (Karig, 1983; Rangin et al., 1985).

These Cenozoic ophiolites are known only in Mindoro and Zambales, whereas Mesozoic ophiolites are widespread throughout the Philippine Archipelago. In Mindoro, the Amnay ophiolite consists of a section of serpentine, gabbro, and pillow basalts, overlain by middle Oligocene red clays (Rangin et al., 1985). The age of these ophiolites is similar to that of the oldest part of the South China seafloor (Anomaly 11; Taylor and Hayes, 1980, 1983), lying immediately to the west. This ophiolite complex is exposed as small thrust slices tectonically transported southwestward above the Cenozoic sediments of the north Palawan block, and later affected by wrench faulting and strike-slip faulting (Sarewitz and Karig, 1986). They are overlain tectonically by pre-Eocene metamorphic sequences including gneisses, marbles and undated metaophiolites. These metamorphic rocks are blanketed by Eocene clastics and carbonates and a late Oligocene-early Miocene volcanic arc sequence (Marchadier and Rangin, 1989). The presence of ophiolites in this suture zone has been interpreted as the result of the oblique collision of the PMB with the North Palawan block, a piece of the South China seafloor thrust within this collision zone (Rangin et al., 1985).

The Zambales ophiolite complex on Luzon consists of at least two distinct members: the Acoje Barlo ophiolite on the west and the Coto ophiolite on the east. The Acoje Barlo ophiolite consists of a Mariana-type tholeiite at the base and middle to late Eocene radiolarites and volcanic ashes above. For the Coto ophiolite, on the other hand, late Eocene to early Oligocene pelagic limestone overlies pillow basalt. These ophiolites can be compared with the results of drilling in the Philippine Sea. The Acoje Barlo ophiolite share similarities with Site 291. Both the Coto and Sierra Madre ophiolites may bear similarities to the section found on the Benham Rise (Site 292). These ophiolites were interpreted by Karig (1983) as having originated in the Celebes Sea, then transported northward along the Philippine fault system.

In Zamboanga, serpentinized peridotites, gabbros, spilite, and undated cherts are imbricated with a metamorphic basement similar to that present in Mindoro and north Palawan (Bureau of Mines and Geosciences, 1982). This Zamboanga terrane could be considered as a rifted fragment from the Palawan block (Rangin, 1989).

\section{SANGIHE ARC AND MOLUCCA SEA}

The Sangihe Arc begins at the northern tip of the north arm of Sulawesi and extends northward to near Mindanao (Fig. 2). This arc lies above the subducted slab of the Molucca Sea Plate (Fig. 3). The Molucca Sea slab is two sided, meaning that the eastern side of the plate is also subducting. The counterpart to the Sangihe Arc is the Halmahera Arc, which lies about $250 \mathrm{~km}$ east of Sangihe. Between the two arcs is a great thickness of highly deformed material, including melange, serpentine, gabbro, metabasalt, shale, and arkose (Silver and Moore, 1978). Most seismicity within the Molucca Sea occurs in the central part of the plate (McCaffrey, 1982), and geophysical data there show the presence of a crustal slab near the surface (McCaffrey et al., 1980). This observation is consistent with the geology of islands within the Molucca Sea (Talaud, Mayu, and Tifore) on which ophiolitic rocks crop out (Silver and Moore, 1978). In the central part of the Molucca Sea, the low-density accreted material attains thicknesses up to $16 \mathrm{~km}$ (McCaffrey et al., 1980). The total cross-arc length of the seismic zone associated with the Molucca Sea collision is approximately $1000 \mathrm{~km}$ (Hatherton and Dickinson, 1969; Silver and Moore, 1978; McCaffrey, 1982), providing a minimum estimate on the width of the basin prior to subduction.

\section{THE NORTH ARM OF SULAWESI}

The north arm of Sulawesi bounds the south margin of the Celebes Basin (Figs. 2 and 3). The north margin of the north arm is a zone of convergence, with the amount of convergence increasing toward the west (Silver et al., 1983). This interpretation is based on seismic reflection lines showing increasing width of the accretionary wedge toward the west. The nature of the east and west ends of the thrust belt are not well determined. Silver et al. (1983) and Hamilton (1979) inferred that the trench ended against a long transform fault, called the Palu fault. This fault in turn connects with the Matano fault, which crosses the south arm of Sulawesi. Considering these faults to mark the path of a small circle about a pole of rotation, the pole lies near the eastern tip of the north arm, providing a ready interpretation for the observed decrease in width of the thrust belt toward the east.

The timing of movement on these faults, and thus the activity on the north Sulawesi thrust, is not well determined. Based on preliminary paleomagnetic studies on the north arm, Otofuji et al. (1981) inferred a clockwise rotation of $90^{\circ}$ between late Eocene and early Miocene time. Structurally, however, the North Sulawesi thrust belt appears to be much younger than late Miocene, so the rotation needed to form the thrust belt may postdate the rotations inferred by Otofuji et al. (1981).

Volcanic activity is not present in the north arm, except at the northernmost tip, where it seems clearly related to westward 
subduction of the Molucca Sea Plate. No thrust activity was observed on the south margin of the north arm. Late Miocene volcanic rocks are present on the north arm, but not Quaternary activity. The exact timing of volcanic cessation is not known, but it appears that much of the presently observed thrusting in the North Sulawesi Trench is not associated with arc volcanism.

Earlier interpretations of the rotation of the north arm assumed a hinge at the intersection of the north and south arms. However, this interpretation would have required deformation south of the arm, not north as we observed. The north arm shows increasing ages to the west, including rocks of Eocene age on the westernmost part of the arm (Ratman, 1976).

\section{BANDA SEA}

The Banda Sea is separated from the Celebes Sea by the complex collision between the island of Sulawesi and the Sula Platform (Figs. 2 and 3). The Banda Sea comprises a complex basin, made up of three elements. The north and south Banda basins attain water depths up to $5000-5500 \mathrm{~m}$ and sediment thicknesses of approximately $1 \mathrm{~km}$. These basins are thought to be trapped fragments of Indian Ocean (Silver et al., 1985; Lee and McCabe, 1986) and/or Molucca or Philippine Sea plates (Silver et al., 1985). Separating these sub-basins are a series of ridges called the Banda Ridges that are composed of a continental margin rock sequence similar to those found in the surrounding islands of New Guinea, the Sula platform, Buru, Buton, Seram, and Misool (Silver et al., 1985). These ridges are considered to represent a displaced and submerged continental borderland (Silver et al., 1985).

\section{TECTONIC SIGNIFICANCE OF THE WESTERN PACIFIC BASINS}

Models have been proposed for these basins, including backarc rifting, rifting of a passive continental margin, trapped ocean basin, and rifting and isolation of a continental borderland. When we view the set of basins from Banda on the south and South China on the north, it appears that each of these mechanisms may be operating. Banda may be a complex basin, composed of a displaced and submerged continental borderland, as well as trapped fragments of once larger ocean basins (Silver et al., 1985). Celebes may be a trapped fragment of any of the Indian Ocean, Philippine Sea, or Molucca Sea crusts. Sulu may represent a back-arc spreading basin, and the South China Sea is widely thought to have formed by rifting of the China continental margin. Drilling is required to ascertain the true nature of each of these basins, but the preponderance of evidence at present suggests that the array of marginal basins in the western Indo-Pacific has had a complex history of development. The Island arc terranes fringing these basins are in the process of being incorporated into the Eurasian margin. That is particularly the case for the Cagayan and Sulu ridges or the Philippine Mobile Belt (Fig. 2). Accretion of these volcanic arcs plays a major role in the continental growth process of eastern Asia. Relict basins, such as the Sulu and Celebes seas, record the history of these island arcs before their incorporation to Eurasia. Estimating the time necessary for development of an island arc and its subsequent collision with a continental margin can provide a semiquantitative approach for the growth of continents. The significance for ancient mountain belts in understanding such complexity is seen when one considers the disproportionately large effect that marginal basins must have had on the character of ancient mountain belts.

The western Pacific basins represent one of the rare places in the world where undeformed oceanic crust can be compared with coeval ophiolites incorporated close by in a recent mountain belt. Complete evolution of an oceanic crust from its gene- sis at a spreading center to its obduction on land can be attempted here, and can be used to constrain the formation of ophiolites.

\section{REFERENCES}

Allen, C. R., 1962. Circum-Pacific faulting in the Philippines-Taiwan region. J. Geophys. Res., 67(12):4795-4812.

Anderson, R. N., Langseth, M. G., Hays, J. E., Watanabe, T., and Yasui, M., 1978. Heat flow, thermal conductivity, and thermal gradient. In Hayes, D. E. (Ed.), A Geological Atlas of the East and Southeast Asian Seas: Boulder, CO (Geological Society of America), MC-25.

Antonio, L. R., 1972. Geology and Mineral Resources of East Central Zamboanga Peninsula, Mindanao, Philippines: Manila (Philippines Bureau of Mines).

Beddoes, L. R., 1976. The Balabac sub-basin, southwestern Sulu Sea, Philippines. Seapex Prog., Offshore Southeast Asia Conf. Pap., No. 15.

Bureau of Mines and Geosciences, 1982. Geology and mineral resources of the Philippines. Philipp. Bur. Mines, Spec. Publ.

Chase, C. G., 1978. Extension behind island arcs and motions relative to hot spots. J. Geophys. Res., 83:5385-5387.

Exon, H. F., Haake, F. W., Hartmann, H., Volger F. C., Müller, P. J., and Whiticar, H. J., 1981. Morphology, water characteristics and sedimentation in the silled Sulu Sea, Southeast Asia. Mar. Geol., 39: 165-195.

Faure, M., Marchadier, Y., and Rangin, C., 1989. Pre-Eocene synmetamorphic nappes in the Mindoro-Romblon-Palawan area (west Philippines) and the bearing in the formation of Eurasia. Tectonics, 8: 963-979.

Fontaine, H., Beauvais, L., Poumot, C., and Vachard, D., 1979. Données nouvelles sur le Mésozoique de l'ouest des Philippines: découverte de Rhetien Marin. C. R. Somm. Sceances, Soc. Geol. Fr., 3:117-121.

Fuller, M., Haston, R., and Schmidtke, E., 1989. Paleomagnetism in Southeast Asia: sinistral shear between the Philippine Sea Plate and Asia. Proc. NATO Adv. Res. Workshop.

Gervaiso, F. C., 1971. Geotectonic developments of the Philippines. $J$. Geol. Soc. Philipp., 25(1):18-38.

Haile, N. S., McElhinny, M. W., and McDougall, I., 1977. Paleomagnetic data and radiometric ages from the cretaceous of west Kalimantan (Borneo), and their significance in interpreting regional structure. J. Geol. Soc. (London), 133:133-145.

Hamilton, W., 1979. Tectonics of the Indonesian region. Geol. Surv. Prof. Pap. (U.S.), No. 1078.

Hatherton, T., and Dickinson, W. R., 1969. The relationship between andesitic volcanism and seismicity in Indonesia, the Lesser Antilles and other island arcs. J. Geophys. Res., 76:5301-5310.

Hawkins, J. W., Moore, G. F., Villomor, R., Evans, C., and Wright, E., 1985. Geology of the composite terranes of east and central Mindanao. In Howell, D. G. (Ed.), Tectonostratigraphic Terranes of the Circum-Pacific Region. Circum-Pacific Counc. Energy Miner. Resour., Earth Sci. Ser., 1:437-463.

Hinz, K., and Schlüter, H. V., 1985. Geology of the Dangerous Grounds, South China Sea, and the continental margin off southwest Palawan: results of Sonne cruises SO23 and SO27. Energy, 10: 297-315.

Holloway, N. H., 1982. The stratigraphy and tectonic relationship of Reed Bank, North Palawan and Mindoro to the Asian Mainland and its significance in the evolution of the South China Sea. AAPG Bull., 66:1357-1383.

Jarrard, R. D., and Sasajima, S., 1980. Paleomagnetic synthesis for Southeast Asia: constraints on plate motions. In Hayes, D. E. (Ed.), The Tectonic and Geologic Evolution of Southeast Asian Seas and Islands. Am. Geophys. Union Monogr., 23:293-316.

Jolivet, L., Huchon, P., and Rangin, C., 1989. Tectonic setting of western Pacific marginal basins. Tectonophysics, 160:23-47.

Karig, D. E., 1983. Accreted terranes in the northern part of the Philippines Archipelago. Tectonics, 2(2):211-236.

Lallemand, S., and Jolivet, L., 1985. Japan Sea: a pull-apart basin earth. Earth Planet. Sci. Lett., 76:375-389.

Lee, C. S., and McCabe, R., 1986. The Banda-Celebes-Sulu basin: a trapped piece of Cretaceous-Eocene crust? Nature, 322:51-53. 
Letouzey, J., and Sage, L., 1988. Geological and Structural Maps of Eastern Asia: Tulsa, OK (AAPG).

Lewis, S. D., and Hayes, D. E., 1983. The tectonic of northward propagating subduction along eastern Luzon, Philippine Islands. In Hayes, D. E. (Ed.), The Tectonic and Geologic Evolution of Southeast Asian Seas and Islands (Pt. 2). Am. Geophys. Union Monogr., 27:57-78.

1984. A geophysical study of the Manila Trench, Luzon, Philippines. 2. Fore-arc basin structural and stratigraphic evolution. J. Geophys. Res., 89(B11):9196-9214.

Linsley, B. K., Thunnel, R. C., Morgan, C., and Williams, D. F., 1985. Oxygen minimum expansion in the Sulu Sea, western equatorial Pacific during the last glacial low stand of sea level. Mar. Micropaleontol., 9:395-418.

Louden, K. E., 1977. Paleomagnetism of DSDP sediments, phase shifting of magnetic anomalies and rotation of the west Philippine basin. J. Geophys. Res., 82:2989-3002.

1980. The crust and lithospheric thicknesses of the Philippine Sea as compared to the Pacific. Earth Planet. Sci. Lett., 50: 275-288.

McCabe, R., Almasco, J., and Diegor, W., 1982. Geologic and paleomagnetic evidence for a possible miocene collision in western Panay, central Philippines. Geology, 10:325-329.

McCabe, R., Almasco, J. N., and Yumul, G. P., 1985. Terranes in the central Philippines. In Howell, D. G. (Ed.), Tectonostratigraphic Terrains of the Circum-Pacific Region. Circum-Pacific Counc. Energy Miner. Resourc., Earth Sci. Ser., 1:421-436.

McCaffrey, R., 1982. Lithospheric deformation within the Molucca Sea arc-arc collision: evidence from shallow and intermediate earthquake activity. J. Geophys. Res., 87(B5):3663-3678.

McCaffrey, R., Silver, E. A., and Raitt, R. W., 1980. Crustal structure of the Molucca Sea collision zone, Indonesia. In Hayes, D. E. (Ed.), The Tectonic and Geologic Evolution of Southeast Asian Seas and Islands. Am. Geophys. Union Monogr., 23:161-177.

Marchadier, Y., and Rangin, C., 1989. Passage subduction-collision et téctoniques superposées à l'extremité méridionale de la fosse de Manille (Mindoro-Tablas: Philippines). C. R. Acad. Sci., Ser. 2, 308:1715-1720.

Mascle, A., and Biscarrat, P. A., 1978. The Sulu Sea: marginal basin in Southeast Asia. In Watkins, J. S., et al. (Eds.), Geophysical Investigations of the Continental Margins. AAPG Mem., 29:373-381.

Mitchell, A.H.G., Hernandez, F., and Dela Cruz, A. P., 1986. Cenozoic evolution of the Philippine Archipelago. J. Southeast Asia Earth Sci., 1(1):3-22.

Molnar, P., and Atwater, T., 1978. Interarc spreading and cordilleran tectonics as alternates related to the age of subducted oceanic lithosphere. Earth Planet. Sci. Lett., 41:330-340.

Moore, G. F., and Silver, E. A., 1982. Collision processes in the northern Molucca Sea. In Hayes, D. E. (Ed.), The Tectonic and Geologic Evolution of Southeast Asian Seas and Islands (Pt. 2). Am. Geophys. Union Monogr., 27:360-372.

Murauchi, S., Ludwig, W. J., Den, N., Hotta, H., Asanuma, T., Yoshii, T., Kubotera, A., and Hagiwara, K., 1973. Structure of the Sulu Sea and the Celebes Sea. J. Geophy. Res., 78(17):3437-3446.

Otofuji, Y., Sasajima, S., Nishimura, S., Pharma, A., and Hehuwat, F., 1981. Paleomagnetic evidence for clockwise rotation of the northern arm of Sulawesi, Indonesia. Earth Planet. Sci. Lett., 54: $272-280$.

Rangin, C., 1989. The Sulu Sea: a back-arc basin setting within a Neogene collision zone. Tectonophysics, 161:119-141.

Rangin, C., Bellon, H., Benard, F., Letouzey, J., Müller, C., and Tahir, S., 1989. Neogene arch continent collision in Sabah: northern Borneo (Malaysia). Tectonophysics.

Rangin, C., Stephan, J. F., Blanchet, R., Baladad, D., Bouysee, P., Pen Chen, M., Chotin, P., Collot, J., Daniel, J., Drouhot, J. M., Marchadier, Y., Marsset, B., Pelletier, B., Richard, M., and Tardy, M., 1988. SeaBeam survey at the southern end of the Manila Trench: transition between subduction and collision processes offshore Mindoro Island, Philippines. Tectonophysics, 146:261-278.

Rangin, C., Stephan, J. F., and Müller, C., 1985. Middle Oligocene ocean crust of South China Sea jammed into Mindoro collision zone (Philippines). Geology, 13:425-428.
Raschka, H., Nacario, E., Rammlmair, D., Samonte, C., and Steiner, L., 1985. Geology of the ophiolite of central Palawan Island, Philippines. Ofioliti, 10:375-390.

Ratman, N., 1976. Geological Map of the Tolitoli Quadrangle, North Sulawesi, 250 000e. Geol. Surv. Indones. Ministr. Mines.

Sarewitz, D. R., and Karig, D. E., 1986. Processes of allochthonous terrane evolution, Mindoro Island, Philippines. Tectonics, 5(4):525552.

Schouten, H., and Cande, S. C., 1976. Paleomagnetic poles from marine magnetic anomalies. Geophys. J. R. Astron. Soc., 44:567-575.

Sclater, J. G., Anderson, R. N., and Bell, M. C., 1971. The elevation of ridges and evolution of the central eastern Pacific. J. Geophys. Res., 76:7688-7715.

Sclater, J. G., Karig, D. E., Lawver, L. A., and Louden, K., 1976. Heat flow, depth, and crustal thickness of the marginal basins of the south Philippine Sea. J. Geophys. Res., 81:309-318.

Silver, E. A., Gill, J. B., Schwartz, D., Praseyto, H., and Duncan, R. A., 1985. Evidence for a submerged and displaced continental borderland, north Banda Sea, Indonesia. Geology, 13:687-691.

Silver, E. A., McCaffrey, R., and Smith, R. B., 1983. Collision, rotation and the initiation of subduction in the evolution of Sulawesi, Indonesia. J. Geophys. Res., 88:9607-9618.

Silver, E. A., and Moore, J. C., 1978. The Molucca Sea collision zone, Indonesia. J. Geophys. Res., 83:1681-1691.

Stephan, J. F., Blanchet, R., Rangin, C., Pelletier, B., Letouzey, J., and Müller, C., 1986. Geodynamic evolution of the Taiwan-Luzon-Mindoro Belt since the late Eocene. Tectonophysics, 125:245-268.

Tapponnier, P., Peltzer, G., Le Dain, A. Y., Armijo, R., and Cobbold, P., 1982. Propagating extrusion tectonics in Asia: new insights from simple experiments with plasticine. Geology, 10:611-616.

Taylor, B., and Hayes, D. E., 1980. The tectonic evolution of the South China basin. In Hayes, D. E. (Ed.), The Tectonic and Geologic Evolution of Southeast Asia Seas and Islands. Am. Geophys. Union Monogr., 23:89-104.

1983. Origin and history of the south China Sea basin. In Hayes, D. E. (Ed.), The Tectonic and Geologic Evolution of the Southeast Asian Seas and Islands (Pt. 2). Am. Geophys. Union Monogr., 27:23-56.

Taylor, B., and Rangin, C., 1988. Tertiary Right Lateral Pull-apart Basins along the Asian-Pacific Margin: Constraints on the Propagating Extrusion Model of Indo-Asian Tectonics. Geodyn. Evol. Eastern Eurasian Margin, Int. Symp., Paris (Abstracts).

United Nations Development Program and the Philippine Bureau of Mines and Geo-Sciences, 1983. Cenozoic geological evolution of southwestern Panay and adjacent areas. Geol. Soc. Philipp.

United Nations, 1985. Geology of Central Palawan. Strengthening the geological survey division of the Bureau of Mines and Geosciences, Ministry of Natural Resources. Rep. Invest., Philipp. Bur. Mines Geo-Sci, Tech. Rep., No. 6.

Uyeda, S., and McCabe, R., 1983. A possible mechanism of episodic spreading of the Philippine Sea. In Hashimoto, M., and Uyeda, S. (Eds.), Accretion Tectonics in the Circum-Pacific Region: Tokyo (Terrapub), 291-306.

Uyeda, S., and Kanamori, H., 1979. Back-arc opening and the mode of subduction. J. Geophys. Res., 84:1049-1061.

Weissel, J. K., 1980. Evidence for Eocene oceanic crust in the Celebes Basin. In Hayes, D. E. (Ed.), The Tectonic and Geologic Evolution of Southeast Asian Seas and Islands. Am. Geophys. Union Monogr., 23:37-47.

Wolfart, R., Cepek, P., Gramann, F., Kemper, E., and Porth, H., 1986. Stratigraphy of Palawan Island, Philippines. Newsl. Stratigr., 16:1948.

Wolfe, J. A., 1981. Philippine geochronology. J. Geol. Soc. Philipp., 35(1):1-30.

1988. Arc magmatism and mineralization in north Luzon and its relationship to subduction at the east Luzon and north Manila trenches. J. Southeast Asian Earth Sci., 2(2):79-93. 